\title{
COMPLEX OF CHEMICAL-TECHNOLOGICAL AND SANITARY-HYGIENIC QUALITY INDICATORS OF THE NEW PASTRY PRODUCTS OF SPECIAL NUTRITION
}

\author{
Yevhenii Kotliar \\ Department of technology of milk, fats and perfume and cosmetic funds \\ Odessa National Academy of Food Technologies \\ 112 Kanatna str., Odessa, Ukraine, 65039 \\ yevhenii11@ukr.net \\ Oksana Topchiy \\ Department of technology of meat and meat products \\ National University of Food Technologies \\ 68 Volodymyrska str., Kyiv, Ukraine, 01601 \\ Oksanatopchiy@ukr.net \\ Liudmyla Pylypenko \\ Department of Biochemistry, Microbiology and Physiology of Nutrition \\ Odessa National Academy of Food Technologies \\ 112 Kanatna str., Odessa, Ukraine, 65039 \\ l.n.pylypenko@ukr.net \\ Inna Pylypenko \\ Department of Biochemistry, Microbiology and Physiology of Nutrition \\ Odessa National Academy of Food Technologies, \\ 112 Kanatna str., Odessa, Ukraine, 65039 \\ inna_p@live.ru \\ Elena Sevastianova \\ Department of technology of milk, fats and perfume and cosmetic funds \\ Odessa National Academy of Food Technologies \\ 112 Kanatna str., Odessa, Ukraine, 65039 \\ Elena.vladimirovn.sevastyanova@mail.ru
}

\begin{abstract}
The complex of chemical-technological and sanitary-hygienic quality indicators of new pastry products of special nutrition was studied. The original recipes of meat pastries for special nutrition, enriched with biologically active components at the expanse of vitaminized blended vegetable oils (VBVO) and protein-fatty emulsions (PFE) on their base, were elaborated. There were elaborated four recipes of pastries of chicken and turkey with PFE, included in recipes in the amount $15 \ldots 20 \%$ and with vitaminized blended vegetable oils of two-component and three-component composition in the amount $10 \%$. Pastry samples, prepared according to SSTC 4432:2005 were used as a control.

VBVO composition and fat-soluble vitamins content in them was determined by the gasochromatographic method.

Molecular-genetic methods were used for the accelerated diagnostics of pastries safety by agents of food intoxications Clostridium perfringens and Bacillus cereus, number of mesophyl aerobic and facultative-anaerobic microorganisms (NMAFAnM), classic ones - colon bacillus group bacteria (CBGB), sulphite reductive clostridia, Staphylococcus aureus, L.monocytogenes, Salmonella. The storage term of products was prolonged in 2 times (48 against 24 hours) according to SSTC). The expedience of their introduction in production was proved.
\end{abstract}

Keywords: pastry products, vitaminized blended vegetable oils, protein-fat emulsions, quality indicators, sanitary-hygienic safety.

\section{Introduction}

The problem of special nutrition is the most important state task, connected with social stability and population health [1-3]. Creation of balanced recipes of pastry products of increased 
food value using vitaminized mixings of vegetable oils with necessary ratio $\omega-6$ : $\omega-3$ of fatty acids and protein-fat emulsions on their base for a partial replacement of animal fats by protein-fat emulsions (PFE) is a prospective way of this problem solution $[4,5]$.

For this aim it is necessary to realize the complex of organoleptic, physical-chemical, biochemical, functional-technological, structural-mechanical, sanitary-hygienic, microbiological and medical-biological studies of new recipes of meat pastries [6, 7]. The limited and short storage term of meat pastries comparing with long classic methods of microbiological studies needs the accelerated control of their sanitary safety $[8,9]$.

Thus, the study of the complex of quality indicators of new pastry products of special nutrition for satisfying new nutritiology [10] is urgent, has the scientific and practical value, favors gene pool and human endoecology saving.

\section{Materials and methods}

The subject of researches is the complex of quality and safety indicators of new meat pastries of balanced composition with vitaminized blended vegetable oils and PFE on their base.

The object of researches is a meat raw material, vegetable oils, vitamin ingredients, fatty-protein complex, experimental meat systems with their use and ready meat pastries.

The organoleptic studies were realized by the tasting group of 10 persons. Physical-chemical quality indicators were determined by standard methods, fatty-acid composition of fats - by the method of gas chromatography according to SSTC ISO 5509-2002 "Oils and fats, animal and vegetable. Preparation of methyl ethers of fatty acids (ISO 5509-2000, IDT)" on the gas chromatograph Hewlett-Packard HP6890 (USA).

The method of fatty-acid composition determination was realized according to SSTC 5509-2002 "Oils and fats, animal and vegetable. Preparation of methyl ethers of fatty acids (ISO 5509-2000, IDT)". Samples preparation was the following: the studied sample was dissolved in $2 \mathrm{ml}$ of heptane. $200 \mathrm{mcl}$ of methanol solution $\mathrm{NaOH}$ was added by a pipette and shaken for 5-10 min, then $1 \mathrm{~g}$ of sodium monohydrate hydrosulphate was added in the solution and carefully stirred up. After salt precipitation, the upper layer with methyl ethers of fatty acids was separated. The received solution was used for chromatography according to SSTC ISO 5508-2001 "Fats and oils, animal and vegetable. Analysis of methyl ethers of fatty acids by the method of gas chromatography (ISO 5508:1990, IDT)". Fatty acids determination was realized on the gas chromatograph, made by Hewlett-Packard HP6890 with the flame-ionizing detector, injector S/S with flows separation, geyser Sp2380, length $100 \mathrm{~m}$, internal diameter 0,25 mm, cover thickness $0,2 \mathrm{mcm}$. Chromatography conditions: injector temperature $280^{\circ} \mathrm{C}$, flow separation $100: 1$, detector temperature $290^{\circ} \mathrm{C}$. Geyser works in the regime of continuous flow with the speed $1,2 \mathrm{ml} / \mathrm{min}$, gas-carrier - helium.Temperature gradient of geysers thermostat $60-250{ }^{\circ} \mathrm{C}$.

The method of tocopherol isomers content determination was realized according to SSTC ISO 9936:2004 "Animal and vegetable fats and oils. Determination of tocopherols and tocotrienols by the method of liquid chromatography of high-resolution (ISO 9936:1997, IDT)".

The method of $\beta$-carotene content determination was realized according to EN 12823-2 "Food products - determination of vitamin A using liquid chromatography. Part 2 - measuring of $\beta$-carotene". Samples preparation and chromatographic system preparation to the work is analogous to tocopherol isomers content determination. The working diapason of $\beta$-carotene mass share determination by this method is $4-500 \mathrm{mg} / \mathrm{kg}$.

Spectroscopic studies were realized on the universal multipurpose analyzer MPA Bruker Optics in the near IR-diaposon with Fourier transformation.

The study of oxidative stability of vegetable oils mixings was realized at different storage modes: by accelerated method of "active oxygen" according to SSTC ISO 6886-2003 "Animal and vegetable oils and fats. Determination of resistance to oxidation (accelerated test for oxidation) (ISO 6886:1996, IDT)"; at room temperature at free access of light and air (autooxidation). Samples of vegetable oils mixings were kept in glasses at the temperature $24 \pm 2{ }^{\circ} \mathrm{C}$. Native fats without oils were used as a control. At storage, samples were taken every 10 days for peroxide, acid and anisidine values determination; under conditions of low-temperature storage without light access. Control and mixed samples of vegetable oils were laid for storage at the temperature $-6 \pm 0,5^{\circ} \mathrm{C}$. 
At the process of storage samples were taken for the analysis every month and peroxide, acid and anisidine values were determined.

Microbiological studies were realized by classic methods according to SSTC, recommendations [11], using chromogen substrate for MAFAnM determination CHROMagar ${ }^{\mathrm{TM}}$ (DRG Techsystems) and elaborated accelerated methods of thermostable (spore-creating) agents of food intoxications determination $[12,13]$. For fast separation and purification of bacterial cellular DNA at polymerase-chain studies was used the set F1021 (SureFast ${ }^{\circledR}$ PREP Bacteria, CONGEN Biotechnologie GmbH, Germany). The composition of mixture for polymerase-chain reaction (PCR) $10 \times \mathrm{PCR}$ buffer $-2 \mathrm{mcl}, 50 \mathrm{mM}$ $\mathrm{MgCl}_{2}-0,8 \mathrm{mcl}, 2,5 \mathrm{mM}$ dNTP $-1,6 \mathrm{mcl}$, Taq-polymerase (5 Un/mcl) - 0,4 mcl. CPR cycles: primary denaturation $-94{ }^{\circ} \mathrm{C} 5 \mathrm{~min}, 30$ cycles of amplification at denaturation $94{ }^{\circ} \mathrm{C} 30 \mathrm{~s}$, annealing at $63{ }^{\circ} \mathrm{C}$ $30 \mathrm{~s}$, elongations at $72{ }^{\circ} \mathrm{C} 30 \mathrm{~s}$ and final elongation $72^{\circ} \mathrm{C} 5 \mathrm{~min}$. The reaction was realized in the amplificatory BioRad (USA).

In the medical-biological studies rats of Wistar line of the mean age (12 months) were used as experimental animals. All animals were divided in 3 groups. The first group (5 rats) - intact animals, were kept on the standard ration; the second group (5 rats) - experimental one, received meat pastry with animal fat; the third group (5 rats) - experimental one received meat pastry with balanced fatty-acid and vitamin composition. The results were processed using "Statistica" program. Experimental data in each group were considered as connected samples and at comparing different groups, as separate samples.

\section{Results}

Taking into account modern requirements to creation of products of special purpose, recipes of new types of pastry products of poultry were elaborated. $10 \%$ of pork fat in them were replaced by vitaminized blended oils of two-component or three-component composition and PFE on their base. To agree them with nutritiology requirements, there was studied the complex of organoleptic, physical-chemical, biochemical, functional-technological, structural-mechanical, sanitary-hygienic and medical-biological indicators.

The main advantage of organoleptic analysis as products quality assessment method is a possibility of relatively fast determination of product fitness for consumption. Such indicators as a color, flavor smell, consistence give a general understanding of a product and indicate the correct choice of main ingredients and their ratio. The results of the organoleptic study are presented in Table 1.

Table 1

Organoleptic indicators of meat pastries $(n=8, p \leq 0,1)$

\begin{tabular}{|c|c|c|c|c|c|c|}
\hline Samples & Appearance & $\begin{array}{l}\text { Appearance } \\
\text { on cut }\end{array}$ & Consistence & Color & Flavor & Smell \\
\hline Control by SSTC $4432: 2005$ & 5,0 & 4,9 & 4,9 & 4,9 & 4,8 & 5,0 \\
\hline $\begin{array}{l}\text { Sample No. } 1 \text { with PFE: } \\
\text { pumpkin }(77,5 \%)+ \\
+ \text { rye }(13 \%)+\text { flax }(9,5 \%)\end{array}$ & 4,7 & 4,5 & 4,8 & 4,7 & 4,2 & 4,3 \\
\hline $\begin{array}{l}\text { Sample No. } 2 \text { with VBVO: } \\
\quad \text { sunflower }(77,5 \%)+ \\
+ \text { rye }(13 \%)+\text { flax }(9,5 \%)\end{array}$ & 5,0 & 4,9 & 4,9 & 4,9 & 4,9 & 5,0 \\
\hline $\begin{array}{c}\text { Sample No. } 3 \text { with PFE: } \\
\text { sunflower }(90 \%)+\text { flax }(10 \%)\end{array}$ & 4,9 & 4,8 & 4,8 & 4,8 & 4,5 & 4,5 \\
\hline $\begin{array}{c}\text { Sample No. } 4 \text { with VBVO: } \\
\text { pumpkin }(90 \%)+\text { flax }(10 \%)\end{array}$ & 5,0 & 4,9 & 4,9 & 4,9 & 5,0 & 5,0 \\
\hline
\end{tabular}

The one of main parameters that influences meat pastry quality is a general chemical composition. 
The results of the study of meat pastry chemical composition are presented in Table $\mathbf{2}$.

Table 2

Chemical composition of meat pastries by protein and fat

\begin{tabular}{|c|c|c|c|c|}
\hline \multirow{2}{*}{ Samples of recipes } & \multicolumn{4}{|c|}{ Mass share, $\%$} \\
\hline & Moisture & Protein & Fat & Ash \\
\hline Control & $66,5 \pm 0,3$ & $18,4 \pm 0,19$ & $14,15 \pm 0,11$ & $0,95 \pm 0,02$ \\
\hline $\begin{array}{l}\text { Recipe No. } 1 \text { with PFE: pumpkin }(77,5 \%)+ \\
+ \text { rye }(13 \%)+\text { flax }(9,5 \%)\end{array}$ & $66,1 \pm 0,3$ & $19,02 \pm 0,17$ & $13,95 \pm 0,14$ & $0,93 \pm 0,02$ \\
\hline $\begin{array}{l}\text { Recipe No. } 2 \text { with VBVO: sunflower }(77,5 \%)+ \\
+ \text { rye }(13 \%)+\text { flax }(9,5 \%)\end{array}$ & $65,8 \pm 0,3$ & $19,17 \pm 0,19$ & $14,10 \pm 0,12$ & $0,93 \pm 0,02$ \\
\hline $\begin{array}{c}\text { Recipe No. } 3 \text { with PFE: snflower }(90 \%)+ \\
+ \text { flax }(10 \%)\end{array}$ & $66,1 \pm 0,3$ & $19,1 \pm 0,18$ & $13,86 \pm 0,14$ & $0,94 \pm 0,02$ \\
\hline $\begin{array}{c}\text { Recipe No. } 4 \text { with VBVO: pumpkin }(90 \%)+ \\
+ \text { flax }(10 \%)\end{array}$ & $66,0 \pm 0,3$ & $18,80 \pm 0,19$ & $14,26 \pm 0,14$ & $0,94 \pm 0,02$ \\
\hline
\end{tabular}

The realized studies of the chemical composition proved that meat pastries, produced by elaborated recipes, are at the same level with the control sample and animal fat replacement by protein-fatty emulsion doesn't worsen their chemical composition, but samples No. 2, No. 4, that contained vitaminized blended oils had less protein than the samples No. 1, No. 3 with PFE.

The most important indicators of food products are functional-technological ones. The change of $\mathrm{pH}$ medium influences not only organoleptic indicators but also microflora development intensity. So $\mathrm{pH}$ medium indicator is an essential factor that influences products quality. Plasticity - products ability to irreversible transformations is also taken into account at products quality assessment.

Using structural-mechanical properties and devices it is possible to control technological parameters of raw material and pastry at any stage of the technological process of its production and also the consistence of ready products.

The protein system is able to bound and to keep moisture. There is the great number of diverse additives of vegetable and animal origin, which main function is the increase of water-bounding ability of a product. The results of the study of functional-technological indicators of pastries are presented in Table 3 .

Table 3

Functional-technological indicators of thermally processed pastries

\begin{tabular}{|c|c|c|c|c|}
\hline Samples of recipes & pH & $\begin{array}{l}\text { Content of bound moisture, } \\
\% \text { to general moisture }\end{array}$ & Plasticity & Output \\
\hline Control & $6,30 \pm 0,06$ & $83,50 \pm 1,31$ & $10,00 \pm 0,30$ & 92,80 \\
\hline $\begin{array}{l}\text { Recipe No. } 1 \\
\text { with PFE }\end{array}$ & $6,25 \pm 0,06$ & $87,83 \pm 1,26$ & $7,80 \pm 0,30$ & 96,80 \\
\hline $\begin{array}{l}\text { Recipe No. } 2 \\
\text { with VBVO }\end{array}$ & $6,33 \pm 0,06$ & $80,28 \pm 1,20$ & $13,20 \pm 0,30$ & 90,40 \\
\hline $\begin{array}{c}\text { Recipe No. } 3 \\
\text { with PFE }\end{array}$ & $6,30 \pm 0,05$ & $87,73 \pm 1,35$ & $8,40 \pm 0,30$ & 96,40 \\
\hline $\begin{array}{l}\text { Recipe No. } 4 \\
\text { with VBVO }\end{array}$ & $6,35 \pm 0,06$ & $81,29 \pm 1,29$ & $12,50 \pm 0,30$ & 90,80 \\
\hline
\end{tabular}


Water-bounding ability values are a bit more in the control sample of meat pastry with animal fat and in meat pastries with vitaminized blended vegetable oils that in ones with PFE. It is conditioned by the fact that samples with PFE have a denser consistence comparing with ones with animal fat. At the decrease of water-bounding ability the product consistence improves, pastry with PFE has the tender consistence. $\mathrm{pH}$ values in samples with PFE don't change comparing with control ones and with samples with vitaminized blended vegetable oils.

In Table 4 is presented the content of monounsaturated and polyunsaturated fatty acids in the studied samples.

Table 4

Group fatty acid composition of pastries with chicken and turkey

\begin{tabular}{|c|c|c|c|}
\hline \multirow{2}{*}{ Name of introduced vegetable oils mixing } & \multicolumn{3}{|c|}{ Fatty acids content, $\%$} \\
\hline & UFA & MUFA & PUFA \\
\hline \multicolumn{4}{|c|}{ Pastries with chicken meat by the recipe No. 1} \\
\hline Sunflower $(77,5 \%)+$ rye $(13 \%)+$ flax $(9,5 \%)$ & 13,35 & 24,74 & 61,91 \\
\hline Sunflower $(90 \%)+$ flax $(10 \%)$ & 13,00 & 24,76 & 62,23 \\
\hline \multicolumn{4}{|c|}{ Pastries with turkey by the recipe No. 2} \\
\hline Pumpkin $(77,5 \%)+$ rye $(13 \%)+$ flax $(9,5 \%)$ & 10,35 & 21,66 & 68,00 \\
\hline Pumpkin $(90 \%)+$ flax $(10 \%)$ & 13,13 & 24,88 & 61,98 \\
\hline
\end{tabular}

From the data of table 4 may be seen that the fat fraction of elaborated pastries contains all groups of fatty acids but their content is unequal. It was established, that near $2 / 3$ of the general fatty acids content belongs to the group of polyunsaturated acids. The content of monounsaturated ones is near $22-25 \%$, and saturated ones - only $10-13 \%$. It confirms the prophylactic directionality of elaborated pastries, because in the aspect of age diseases prevention, the content of unsaturated components of fat must be as high as possible. Especially, among monounsaturated fatty acids the most important is oleic one C18:1 that decreases the level of undesirable cholesterol-LDL (low density lipoproteins).

In the connection with the fact that vegetable oils consist of easily oxidized unsaturated fatty acids, a degree of their preservation in ready pastries that underwent thermal processing up to $72{ }^{\circ} \mathrm{C}$ in a product center was verified. For that the content of fatty acids was checked up before and after the thermal processing of products, made by elaborated recipes. It was established, that $95 \%$ of initial fatty components are preserved in elaborated samples after the thermal processing.

Last time the serious problem of dieticians is a rate of fatty acids cys- and trans-isomers content. Most natural fatty acids are in cys-form. It is generally acknowledged, that trans-fatty acids are an artificial element, able to increase cholesterol level in blood serum and provoke human atherosclerosis development, to influence the speeds of substrates oxidation in heart muscle mitochondria, triglycerides synthesis and to disturb the normal properties of the lipid fraction of cellular membranes.

On the Fig. 1 is presented the comparative characteristic of fatty acids trans-isomers content in elaborated meat pastries comparing with recommendations of world health protection organizations of developed world countries [14].

On the Fig. 1 may be seen that the revealed content of trans-isomers doesn't exceed World norms, declared by WHO, EFSA (European food safety agency) and the Institute of RAMS. In Ukraine the content of oleic acid trans-isomers is regulated only by SSTC 4445:2005 "Fatty spreads and mixtures. "General technical conditions", they are contained in spreads and margarines in the amount no more than $8 \%$, in fats with excessive ethers - no more than $10 \%$ and in fats for milk industry - no more than $15 \%$. 


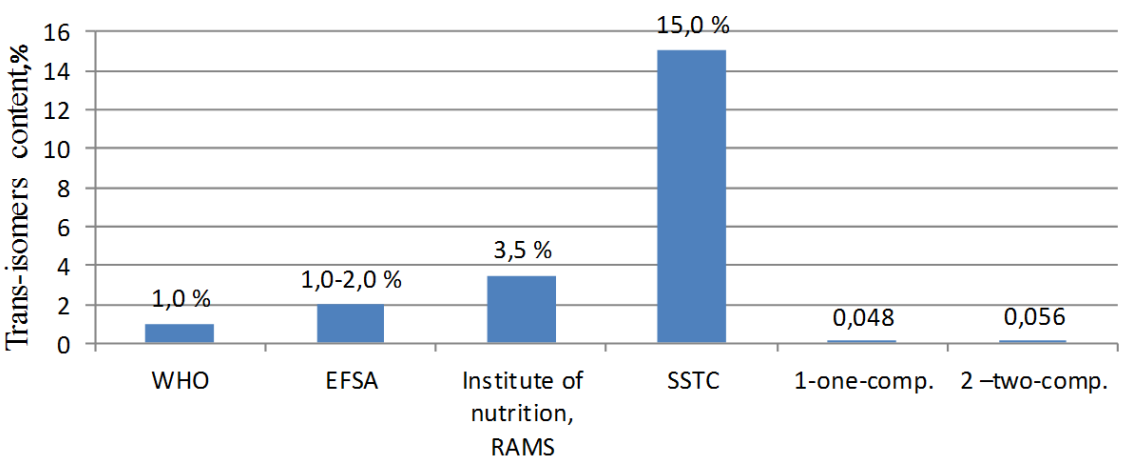

Fig. 1. Content of trans-isomers of fatty acids in pastries with chicken by the recipe No. 1 and recommendations of scientists and SSTC

Thus, it may be stated by the results of the studies that elaborated pastries correspond to the requirements to a product of special nutrition by the indicator of biological balance of fatty acid composition.

The accelerated assessment of the presence of regulated thermostable microorganisms was carried out by the molecular-genetic methods - PCR. Especially for verification of reliability and specificity of the method of $C$. perfringens revelation in elaborated products, the results of amplification of $16 \mathrm{~S}$ кRNA $C$. perfringens gene were compared with PCR of genome DNA, separated from other bacteria $\left(5 \times 10^{5}\right.$ cells $)$, presented on the Fig. 2 .

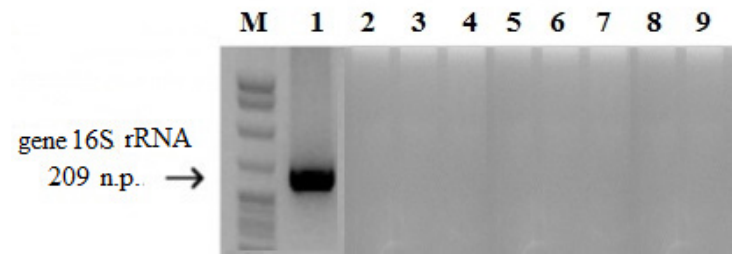

Fig. 2. Results of $16 \mathrm{~S}$ rRNA C. perfringens (209 n. p.) gen amplification by PCR method comparing with PCR of genome DNA, separated from other bacteria, strips: $1-C$. perfringens; 2 -C. butyricum; 3 - C. sporogenes; 4 -Lactobacillus plantarum; 5 -Bacillus licheniformis;

6 - B. subtilis; 7 - Staphylococcus aureus; 8 - Bifidobacterium adolescentis; 9 - B. cereus; $\mathrm{M}$ - DNA markers

The model connections of meat pastries, contaminated by strains C. perfringens and B. Cereus were also studied. To reveal microorganisms of Bacillus cereus group, PCR was realized with group specific primers to groEL gen, and to determine Bacillus cereus microorganisms - with specie specific primers to nhe $A$. gen. At that amplification products were created with sizes 400 and 553 n. p. respectively. The results of the studies of pastries demonstrated the absence of agents of food intoxications in them that corresponds to regulated norms.

The amount of vestigial microflora correlates with initial one: it is more, the more pastry forcemeat contamination by microogranisms before the thermal processing is. More bacteria survive in meat pastries with the high content of fat, because fat creates a safe zone around their cells.

After baking meat pastries are fast cooled to avoid reproduction of vestigial microflora in them. At storage of these products takes place the secondary surface infection and gradual increase of bacteria number. The amount of microflora grows faster, the higher storage temperature and relative air humidity are.

That is why microbiological safety at storage was studied by the following parameters for all elaborated recipes:

MAFAnM - at the normative permissible value according to SSTC 4432:2005 $1000 \mathrm{NCU} / \mathrm{g}$ was $130,280,1300 \mathrm{NCU} / \mathrm{g}$ on first, third and fifth day respectively; CBGB, Sulphite reductive clostridia in 0,1 $\mathrm{g}$ of product, Staphylococcus aureus in $1 \mathrm{~g}$ of product, L. monocytogenes in $25 \mathrm{~g}$ of 
product and Salmonella in $25 \mathrm{~g}$ of product, that are not permitted, were not also revealed. Just this fact together with other indicators of new products quality allowed to increase their storage term in 2 times (up to 48 hours).

In the medical-biological studies linear rats of the mean age (12 months) were used as experimental animals. All animals were divided in 3 groups. The first group ( 5 rats $)$ - intact animals, were kept on the standard ration; the second group ( 5 rats $)$ - experimental one, received meat pastry with animal fat; the third group (5 rats) - experimental one received meat pastry with balanced fatty-acid and vitamin composition. The content of cholesterol, protein and triglycerides in blood at the beginning of the studies and in 21 days are presented on the Table $\mathbf{5}$.

Table 5

Content of cholesterol, protein and triglycerides in at the beginning of the studies and in 21 day

\begin{tabular}{cccccccc}
\hline \multirow{2}{*}{ Studied groups } & \multirow{2}{*}{ Duration } & \multicolumn{2}{c}{ Cholesterol, mmol/l } & \multicolumn{2}{c}{ Protein g/l } & \multicolumn{2}{c}{ Triglycerides, mmol/I } \\
& & Content & Norm & Content & Norm & Content & Norm \\
\hline \multirow{2}{*}{1 group (5) } & At the beginning & 5,6 & $3,1 \ldots 5,2$ & 58 & $65 \ldots 85$ & 0,40 & $0,5 \ldots 1,8$ \\
& After 21 days & 5,6 & $-/ /-$ & 58 & $-/ /-$ & 0,40 & $-/ /-$ \\
2 group (5) & At the beginning & 5,6 & $-/ /-$ & 56 & $-/ /-$ & 0,39 & $-/ /-$ \\
& After 21 days & 5,1 & $-/ /-$ & 60 & $-/ /-$ & 0,50 & $-/ /-$ \\
3 group (5) & At the beginning & 5,4 & $-/ /-$ & 54 & $-/ /-$ & 0,40 & $-/ /-$ \\
& After 21 days & 3,6 & $-/ /-$ & 78 & $-/ /-$ & 0,80 & $-/ /-$
\end{tabular}

\section{Conclusions}

1. The complex of chemical-technological and sanitary-hygienic indicators of new pastry products quality demonstrated their correspondence to the modern requirements of special nutrition.

2. According to nutritiological requirements, there was grounded the choice of vegetable oils and it was established that the use of $10 \%$ of VBVO or $20 \%$ of PFE on their base in meat pastries has a positive influence on the complex of their organoleptic, physical-chemical, biochemical, functional-technological, structural-mechanical, sanitary-hygienic and medical-biological indicators, proves the expedience of the joint use of tocopherol and $\beta$-carotene and allows to stabilize oxidation and increase the period of induction in $1,5 \ldots .2$ times.

3. The accelerated and strict control of new products by the presence of thermostable agents of food intoxications that is especially important for pastry products with regulated terms and conditions of realization, allows to use modern molecular-genetic studies. On the base of the realized complex of physical-chemical and microbiological studies of meat pastries it was established that that at the expanse of VBVO addition their guarantee storage term increases in 2 times (up to 48 hours).

4. The positive endoecological influence of meat pastries, balanced by fat and vitamin component, was proved by the medical-biological studies of animal organism. It was revealed that the addition of the product in rats' food ration influences lipid and protein metabolism normalization: cholesterol content decreased by $1,8 \mathrm{mmol} / 1$ (34,6 \% to the initial level), and the amount of protein and triglycerides increased by $24 \mathrm{~g} / \mathrm{l}$ and $0,4 \mathrm{mmol} / \mathrm{l}(28,2 \%$ and $22,2 \%$ relative to the initial level).

In further work with the complex of studied parameters we plan to improve safety and quality of new types of meat products using exogenous biooxidants at adding VBVO and PFE on their base, a possibility of prolonged guarantee term of their storage may be realized using molecular-genetic methods of the accelerated indication of their quality.

\section{References}

[1] Peshuk, L., Karpenko, O. (2005). Perspektyva rozrobky speciaĺnych produktiv charčuvannia na mjasnij osnovi. Tehnologu na zametku, 2 (31), 14-15. 
[2] Zakon Ukrajiny pro jakist' ta bezpeku charčovych produktiv i prodovoĺčoji syrovyny zi zminamy. (2005). Available at: http://consultant.parus.ua/?doc=01NAWB64D5

[3] Jiménez-Colmenero, F. (2007). Healthier lipid formulation approaches in meat-based functional foods. Technological options for replacement of meat fats by non-meat fats. Trends in Food Science \& Technology, 18 (11), 567-578. doi: 10.1016/j.tifs.2007.05.006

[4] Topčij, O., Kotliar, Je. (2015). Principles of blending fatty acid balanced vegetable oils. Eastern-European Journal of Enterprise Technologies, 1 (6 (73)), 26. doi: 10.15587/1729-4061.2015.35997

[5] Smith, J., Charter, E. (Eds.). (2010). Functional Food Product Development. Blackwell Publishing Ltd, 528. doi: 10.1002/9781444323351

[6] Mohamed, K. M., Elsanhoty, R. M., Hassanien, M. F. R. (2013). Improving Thermal Stability of High Linoleic Corn Oil by Blending with Black Cumin and Coriander Oils. International Journal of Food Properties, 17 (3), 500-510. doi: 10.1080/10942912.2012.654560

[7] Dierick, K., Van Coillie, E., Swiecicka, I., Meyfroidt, G., Devlieger, H., Meulemans, A., Mahillon, J. (2005). Fatal family outbreak of Bacillus cereus-associated food poisoning. Journal of clinical microbiologyl, 43 (8), 4277-4279.

[8] Borchers, A., Teuber, S. S., Keen, C. L., Gershwin, M. E. (2009). Food Safety. Clinical Reviews in Allergy \& Immunology, 39 (2), 95-141. doi: 10.1007/s12016-009-8176-4

[9] Yamborko, H., Ostapchuk, A., Serhieieva, Zh., L. M. Pylypenko, L., Pylypenko, I. (2017). Khemotaksonomichni osoblyvosti ta plazmidni profili aerobnykh ta fakultatyvno-anaerobnykh sporoutvoriuvalnykh bakterii z ovochevoi produktsii. Mikrobiolohiia i biotekhnolohiia, 1 (37), 56-72.

[10] Astley, S. B., Elliott, R. M. (2007). The European Nutrigenomics Organisation: linking genomics, nutrition and health research. Journal of the Science of Food and Agriculture, 87 (7), 1180-1184. doi: $10.1002 /$ jsfa. 2791

[11] Pylypenko, I., Pylypenko, L., Sevastyanova, E., Kotlyar, E., Kruchek , R. (2016). Epiphytic and regulated microbial contaminants of food vegetable raw materials and products. Ukrainian Food Journal, 5 (2), 272-280. doi: 10.24263/2304-974x-2016-5-2-6

[12] Melngaile, A. (2008). Mitsrobologitsal risk analysis in publits tsatering establishments. Summary of Dotstoral Thesis, Yelgava, 64.

[13] Sava, V., Pylypenko, L., Pylypenko, I. (2014). Pat. No. 111266 UA. Sposib vyznachennia Tslostridium perfringens kharchovykh produktakh MPK S2 (2016.01). No. a 2014 09534; declareted: 29.08.2014 published: 11.04.2016, Bul. No. 7.

[14] Demydov, Y., Kuznetsova, L. (2011). Zhiry, ispol'zuemye dlja fritjura, problemy kachestva i bezopastnosti. Tehnologii i oborudovanie pishhevyh proizvodstv, 146-152. 